\title{
Effect of seedling age, seeding density and nitrogen fertilizer on growth and grain yield of rice (Oryza sativa L.)
}

\author{
Saroj Thapa ${ }^{1}$, Khagendra Thapa ${ }^{1}$, Jiban Shrestha ${ }^{2}$ \& Amit Chaudhary ${ }^{1}$ \\ ${ }^{1}$ Agriculture and Forestry University, Rampur, Chitwan, Nepal \\ ${ }^{2}$ Nepal Agricultural Research Council, Agriculture Botany Division, Khumaltar, Lalitpur, Nepal
}

\begin{abstract}
Rice (Oryza sativa L.) is first staple crop of Nepal. The national average yield of rice is less than its potential yield, for which poor agronomic management has been reported as the critical factor. Among various agro-management practices seedling age, seeding density and nitrogen rates significantly affect the growth and yield of rice. The lower seeding density produces the taller plant, more effective tiller, lower sterility and higher grain yield. On the other hand, seedling of older age from higher seeding density gives the lowest yield. Transplanting younger seedling with low seeding density and application of recommended dose of nitrogen gives a higher yield. This article summarizes various effects of seedling age, seeding density and nitrogen rates on plant height, number of effective tillers, number of filled grains, thousand grain weight and grain yield of rice. This information may be useful for maize growers and researchers.
\end{abstract}

Article History

Received 12 May 2019

Accepted 24 June 2019

Keyword

Rice Oryza sativa L.

growth, grain yield, Nitrogen (N), Seedling age, seeding density.

\section{Introduction}

Rice (Oryza sativa L.) is considered as the most important staple food crop in Nepal, followed by maize (Zea mays L.) and wheat (Triticum aestivum L.) respectively. Rice is cultivated in wide range of altitude from plain of Terai to Jumla (3050 metre above sea level) of high hill region of Nepal (NARC, 2007). Total rice cultivated area in Nepal is 1.36 million ha with total production of 4.3 million ton (t) (CBS, 2015-16). The yield of rice in Nepal and world context are 3.16 and $4.36 \mathrm{t} \mathrm{ha}^{-1}$ respectively (FAOSTAT, 2012). Dependency of rainwater, low input use and poor crop management practices are the major causes of low rice yield in Nepal (AICC, 2018). Nepal has still very low productivity compared to other developed countries though rice is major cereal crop for Nepal and its high yielding varieties are already available in global market. There is huge gap between rice productivity at researcher level and farmer's field. It is so because farmers are still unable to do proper nursery as well stand crop management. Padalia (1980) and Lal and Roy (1996) concluded seedling health determines the final yield of transplanted rice. Practices of proper nursery management, integrated nutrient and pest management, maintenance of proper seedling density and timely 
transplantation of seedling can improve growth and development of rice plant (Naeem Sarwar, 2011; Subedi, 2013).

Rainfed rice covers $79 \%$ proportion of total rice produced in Nepal. Among it, distribution of rainfed rice in lowland and upland area are 70 and $9 \%$ respectively (CBS, 2015/16). Irregular and insufficient rainfall occurrence has delayed the transplantation date of seedling which has been reducing the final yield of rice (Mishra and Salokhe, 2008) as plant height, tiller production, panicle length, grain formation, grains per panicle, and other yield attributing characters are highly affected due to delayed transplantation of seedling (Ali et. al., 1995). Reduction of primary tiller occurs due to detoriation of buds in older seedlings as the consequence of delayed transplantation (Mobasser, 2007).

Sufficient nutrient supply in rice nursery helps to enhance the dry weight, height, root density, root length and overall growth as well development of seedling (Singh, 2005). Proper growth and good final yield is obtained only after proper management of rice seedlings at their young stage and also using of healthy seedlings. Reduction in seedling mortality, enhancement in stress tolerating capacity, increased number of effective tillers etc. are possible as the result of optimum application of nitrogenous fertilizers in nursery time and using of good seedlings only. About $50 \%$ and $100 \%$ more dry matter accumulation have been observed in rice seedlings due to application of nitrogen and phosphorus in nursery (Ros et al., 1997). Maximum rice productivity $\left(4.9 \mathrm{t} \mathrm{ha}^{-1}\right)$ have been observed after the application of di-ammonium phosphate and single super phosphate @ $50 \mathrm{~kg} \mathrm{P}_{2} \mathrm{O}_{5} \mathrm{ha}^{-1}$ in nursery. It valued $21 \%$ more yield compared to control method (Rajagopalan and Krishnarajan, 1987).

Practice of sufficient water supply, labour, weed management including other inputs that determines the optimum age of seedlings to be transplanted for better grain yield. In case of lowland field, seedlings of 25 to 50 days old are used for transplantation by farmers (Wagh, 1988). Previous researches has shown better yield when seedlings are transplanted before it gets 25 days old (Rao, 1987; Wagh, 1988). Researches has directed towards the yield performance of rice when transplanted under age of 20 days old although findings are still contradictory (NARC, 2004). Few researchers have studied the synergistic influence of seedbed management on the characteristics of younger/older seedlings and the consequent impact on plant growth and yield after transplanting. Thus the objectives of this study were to quantify the distinctive effects of nursery management and seedling age on yield and yield components of fine rice

\section{Materials and Methods}

Relevant literatures from 1980 to 2018 were collected from journal articles, books, dissertations and working papers on Effect of seedlings age, seeding density and nitrogen fertilizer on growth and grain yeld of rice. Web pages were visited and the relevant information was collected. Author's experience in agriculture intensification is also internalized in the paper. Finally, information collected from different sources were analyzed and presented.

\section{Results and Discussion}

\section{Plant Height}

Both the environment as well as crop management practice effect the height of plant which is one of the major parameter determining growth status of plant. Nutrient management, health of young seedlings, crop field environment and genetic characteristics 
also determine height of plant (Yoshida, 1981). Crop geometry of $20 \times 15 \mathrm{~cm}$ found to be significantly increasing tiller number and plant height compared to spacing of $20 \times 10 \mathrm{~cm}$, $20 \times 25 \mathrm{~cm}$ or $20 \times 20 \mathrm{~cm}$ (Nayak et al.,2011). Transplantation of the younger seedling of 12 days old showed significantly taller plant height as compared to 30 days older seedlings in case of rice (Mishra and Salokhe, 2008). Similarly, compared to 21 days old seedlings, 7 and 14 days old younger seedlings produced significantly taller plant height of rice (Gani et al., 2002). Insufficient fertilizer application and maintaining higher seedling density in nursery significantly reduces plant height (Naeem Sarwar, 2011). Seedling health mainly depend upon nutrient management during its early growth stage (Mishra and Salokhe, 2008). Both the process of cell division and elongation are responsible in improvement of plant height. Significant increment in dry matter accumulation as the result of higher photo assimilates due to larger leaf area by the action of optimum utilization of nitrogenous fertilizer have been observed in rice plant (Chaturvedi, 2005; Zhilin et al., 1997). Longer root length, higher root density, lesser transplantation shock due to lesser leaf area and good health of younger seedlings are responsible for increasing cell division and elongation process which ultimately increases plant height (Sangsu et al., 1999; Rahman, 2001). Better seedlings used for transplantation showed significant enhancement of plant height (Farooq, 2007).

\section{Effective tillers}

Effective tiller number can be increased by using nitrogenous fertilizer (Budhar and Palaniappan, 1996). The combined practice of using $N$ fertilizer and low seeding density during nursery management can increase the number of productive tiller of rice seedlings. On other hand, if nitrogenous fertilizer was not applied then the number of effective tiller found to be higher for high seeding density than low seedling density (Subedi, 2013). Generally, lower seeding density favours the number of effective tillers significantly (Sarwar, 2011). It has also been observed that in case of high seeding density, there were no tiller formation occurred as compared to low seeding density when 40 days old seedlings were used for transplantation. The age of seedling also effects the effective tiller number significantly. Comparison to younger seedlings, older seedlings have more number of productive tillers (Adhikari, 2013). Mobasser (2007) found that higher number of effective trillers ( 355 effective tillers $\mathrm{m}^{-2}$ ) was produced in case of 45 days older seedlings as compared to younger ones. If young seedlings of 12 days old are transplanted then higher number of effective tillers are produced independent to amount of nitrogenous fertilizer applied and seeding density maintained in nursery (Mishra and Salokhe, 2008). This result occurs due to proper growth and development of root, increased cell division and enlargement process which are the intermediary consequence of increased photo assimilate. These enhanced processes finally increases the height of plant as well as tiller density in rice (Shrirame et al., 2000; Vijayakumar et al., 2005; Salem et al., 2011).

\section{Number of filled grains}

The number of filled grains per panicle is also one of the essential yield attribute. The number of filled grains per panicle has been found to be significantly higher in case of low seeding density compared to medium seeding density but result was not significant compared to high seeding density. There was also non-significant difference between effect of medium and high seeding density on filled grain number per panicle. Comparison to transplanted older seedlings, younger seedling led to higher number of filled grains (Subedi, 2013). Highest number of filled grains produced in case of transplanted 45 days old seedlings among 
transplanted 30, 60 and 75 days old seedlings (Khatun, 2002). Despite of significant effect of seedling age on filled grain number, there was no significant effect seen on amount of nitrogen fertilizer application done in nursery. Whereas, Mursal (2008) found that number of tiller per clump, seed weight and number of seed per panicle increased due to application of $\mathrm{N}$ fertilizer application. Huge or low amount of $\mathrm{N}$ application can lead to decreased filled grains number per panicle. The relation observed is that enormous amount of $\mathrm{N}$ utilization increases number of filled grains and also reduce number of unfilled grains.

\section{Thousand grain weight}

The 1000 grain weight being an essential yield attribute mainly depends upon genetic characteristic of that plant compared to environmental influence (Ashraf, 1999). Optimum utilization of fertilizer significantly enhances the 1000 grain weight value (Panda, 1991). Rice crop management with high seeding density, no nitrogen application and use of older seedling significantly reduces 1000 grain weight than compared to optimum management including practices of low seeding density, optimum $\mathrm{N}$ application and transplantation of younger seedlings (Saha, 1979; Sarwar, 2011).The low nitrogen application of @ $150 \mathrm{~kg} \mathrm{ha}^{-1}$ produced significantly higher test weight than compared to higher nitrogen level of $200 \mathrm{~kg}$ $\mathrm{ha}^{-1}$. It may have happen due to excessive growth of rice plant creating quite large number of spikelet which caused deficiency of carbohydrates require to fill all the empty grains reducing dry matter accumulation. This finally reduced the test weight of rice crop (Pramanik and Bera, 2013; Channabasavanna and Setty, 1994; Raju and Reddy, 1993). Furthermore, Hasegawa et al. (1994) also supported the result of reduced dry matter accumulation due to application of high amount of nitrogen in rice.

\section{Grain Yield}

The factors including seeding density, $\mathrm{N}$ fertilizer application and seedling transplanting age have shown significant interactive effect on final grain yield of rice. Grain yield is reduced when practice of high seeding density and older seedlings transplantation with or without using $\mathrm{N}$ fertilizer are used. The amount and quality of grain can also be effected by types of nitrogenous fertilizer used for cultivation (Gately and Kelly, 1987). Urea is considered as cheaper nitrogenous fertilizer that also don't have detrimental effect on amount and quality of rice grain yield. Gately et al. (1988) found that higher grain yield as the positive effect of calcium ammonium nitrate application which also have higher amount of $\mathrm{N}$ content compared to urea. Ebaid and Ghanem (2000) reported that application of nitrogen up to $144 \mathrm{~kg} \mathrm{ha}^{-1}$ enhanced the growth of crop as well as its final grain yield too. El-Batal et al. (2004) found that plant height, panicle length, no. of filled grains panicle $e^{-1}$ and grain yield significantly increased when nitrogen dose increased between 120 to $190 \mathrm{~kg} \mathrm{ha}^{-1}$. Likewise, Yoseftabar (2013) higher plant growth, yield attributes and grain yield obtained as the result of nitrogen application done at the rate of 100,200 and $300 \mathrm{~kg} \mathrm{ha}^{-1}$ respectively.

Comparison to practice of high seeding density, older seedlings, with or without nitrogen application has produced minimum grain yield $\left(5.74 \mathrm{t} \mathrm{ha}^{-1}\right)$ which is significantly lower compared to yield of $6096 \mathrm{t} \mathrm{ha}^{-1}$ obtained as the result of low seeding density, younger seedlings and with or without $\mathrm{N}$ application. Result found to be non-significant for low, medium and high seeding density in case of young seedling transplantation and without $\mathrm{N}$ application (Subedi, 2013). Higher competitive condition for plant growth and changes in pattern of growth are caused by late transplantation of seedling (Mandal, 1984). Higher development of plyllocron and higher effective tiller number per plant which finally increases 
grin yield. This result is obtained by the transplantation as younger seedlings (De Datta, 1980). Moreover, younger seedlings of 20 days old maintaining low seeding density of $100 \mathrm{~g} \mathrm{~m}^{-2}$ and with $\mathrm{N}$ application when transplanted in field produced maximum grain yield of $6.96 \mathrm{t} \mathrm{ha} \mathrm{h}^{-1}$ (Subedi, 2013).

\section{Conclusions}

The transplanting younger seedlings produces the maximum yield, irrespective of nursery management. The seedlings obtained from high seeding density should not be transplanted at older age because it reduced the yield of rice drastically. Transplanting younger seedling with low seeding density and application recommended dose of nitrogen gives higher yield

\section{References}

Adhikari, B., Mehera, B. \& Haefele, S. 2013. Impact of Rice Nursery Nutrient Management, Seeding Density and Seedling Age on Yield and Yield Attributes. American Journal of Plant Sciences, 4:146-155.

AICC. 2018. Krishi Diary 2018. Agriculture Information and Communication Center. GoN.

Ali, M., Rahman,M.M. \& Haq, M.F. 1995. Effect of time of transplanting and age of seedling on the performance of late planted aman rice. Bangladesh J Sci Ind Res., 30(1): 45-58.

Ashraf, M. A. 1999. Effect of seedling age and density on growth and yield of rice in saline soil. Pak. J. Bio. Sci , 2(3): 860-862.

Budhar, M. N. \& Palaniappan, S. P.1996. Effect of integration of fertilizer and green manure nitrogen on yield attributes, nitrogen uptake and yield of lowland rice (Oryza sativa L.).Journal of Agronomy and Crop Science, 176:183-187

CBS. 2015-16. Statistical Year Book of Nepal. His Majesty's Government of Nepal. Central Bureau of Statistics, National Planning Commission, Kathmandu, Nepal.

Channabasavanna, A. S. \& Setty, R.A. 1994. Response of broadcast rice (Oryza sativa) to level of nitrogen, phosphorus and potassium and time of $\mathrm{N}$ application. Indian Journal of Agronomy, 39(3):457-459.

Chaturvedi, I. 2005. Effect of nitrogen fertilizers on growth, yield and quality of hybrid rice (Oryza sativa). Journal of Central European Agriculture, 6(4): 611-618

De Datta, S. 1980. Principles and practices of rice production. Singapoor.

Ebaid, R.A. \& Ghanem, S.A., 2000. Productivity of Giza 177 rice variety grown after different winter crops and fertilized with different nitrogen levels.Egypt J. Agric. Res., 78: 717731

EL-Batal, M.A., Abd EL-Gawad, M.H., Abdo, F.A., EL-Set, A.\& EL-Aziz, A. 2004. Uniconazole application as anti-lodging for rice plants fertilized with high nitrogen rate.Zagazig J. Agric., Res., 31: 473-490.

FAOSTAT. 2012. Food and Agriculture data. http://www.fao.org/faostat/en/\#home

Farooq, M., Basra, S. M. A. \& Ahmad, N. 2007. Improving the Performance of Transplanted Rice by Seed Priming. Plant Growth Regulation, 51: 129-137.

Gani, A., Rahman, A., Rustam, D. \& Hengsdi, H.2002. Synopsis of water management experiments in Indonesia. In B. A. M. Bouman, Hengsdijk, A., Hardy, B., Bindraban, P.S., Tuong, T.P., Ladha, J.K (Ed.), Water-wise rice production: IRRI, Phillipines. 
Gately, T.F. \& Kelly, D. 1987. Sources of nitrogen for spring barley. Soils and Grassland Production Research Report, pp 27-8. Dublin. A ForasTaluntais.

Gately, T.F., Quirke, L. \& Ormonde, S.1988. Sources of nitrogen for spring barley. Soils and Grassland Production Research Report, pp 14-15. Dublin. AnForasTaluntais

Hasegawa, T., Koroda, Y., Seligma, N.G. \& Horie, T. 1994. Response of spikelet number to plant nitrogen concentration and dry weight in paddy rice. Agronomy Journal, 86: 673-676.

Khatun, A., M. I. 2002. Seasonal Effect of Seedling Age on the Yield of Rice. Pakistan Journal of Biological Sciences, 5: 40-42.

Lal, M., and R.K. Roy. 1996. Effect of nursery seeding density and fertilizer on seedling growth and yield of rice. Indian Journal of Agronomy, 41:642-644.

Rajagopalan, S. \& Krishnarajan, J. 1987. Effect of nursery management technique on phosphorus nutrition of rice in mainfield. Oryza, 24, 199-209.

Mandal, B.K. \& Ray, P. K.1984. Effect of age of seedlings and nitrogen levels on the growth and yield of Mahsuri. Indian J. Plant Physio, 27(3): 303-306

Mishra, A. \& Salokhe, V.M. 2008. Seedling characteristics and the early growth of transplanted rice under different water regimes. Experimental Agriculture, 44:1-19.

Mobasser, H. D. 2007. Effect of seedling age and planting space on yield and yield components of rice (Neda variety). Asian J. of Plant Sciences , 6: 438-440.

Mursal, E.A.D. 2008. Effect of Nitrogen and Phosphorus Fertilizer on Growthand Yield of Rice (Oryzasativa) In White Nile State - Sudan. A Thesis Submitted to the University of Khartoum in Partial Fulfillment of the Requirement for the Degree of Master of Science (M.Sc.) in Agronomy. Pp. 47.

Naeem Sarwar, M. M.-u.-H. 2011. Impact of nursery seeding density, Nitrogen, and seedling age on yield and yield attributes of fine rice. Chilean Journal of Agricultural Research, 3: 71.

NARC. 2007. "Research Highlights: 2002/03-2006/07," . Communication, Publication and Documentation Division, Nepal Agricultural Research Council (NARC).

Nayak, B.C., Dalei, B.B. \& Chodhury, B.K.2011. Response of hybrid rice to date of planting, spacing and seedling rate during wet season. Ind. J. Agron., 48: 172-174.

Padalia, C.R. 1980. Effect of age of seedling on the growth and yield of transplanted rice. Oryza, 81:165-167.

Panda, M. M. 1991. Yield performance of rainfed lowland rice as affected by nursery fertilization under conditions of intermediate deep water $(15-50 \mathrm{~cm})$ and flash flood. Plant and Soil , 132:65-71.

Pramanik, K., \& Bera, A. K. 2013. Effect of Seedling Age and Nitrogen Fertilizer on Growth, Chlorophyll Content, Yield and Economics of Hybrid Rice (Oryza sativa L.). International Journal of Agronomy and Plant Production, 4: 3489-3499.

Rahman, M.M. 2001. Effect of seedling age and spacing on the productivity of hybrid rice Sonarbangla-1. M.Sc. Thesis, Dept. Agronomy. BAU, Mymensingh.

Raju, R. A. \& Reddy, K. A. 1993. Response of winter rice (Oryza sativa) to nitrogen, phosphorus, and potassium fertilization on Godavari alluvial. Indian Journal of Agronomy, 38(4): 637-638.

Rao, C.A. 1987. Effect of age of seedling, nitrogen and spacing on rice. Indian Journal of Agronomy, 32:100-102. 
Ros, C., Bell, R.W. \& White, P.F. 1997. Effect of Nursery Applications of N and P on Rice Yield. Kasetsart Journal: Natural Science, 31: 96-105.

Saha, K. S. 1979. Effect of Age of Seedlings at Normal Transplanting on Growth and Yield of Rice Varieties. Indian Journal of Agricultural Sciences, 49: 797-801.

Salem, A.K.M., ElKhoby, W.M., Abou-Khalifa, A.B. \& Ceesay, M. 2011. Effect of Nitrogen Fertilizer and Seedling Age on Inbred and Hybrid Rice Varieties. American-Eurasian Journal of Agricultural and Environmental Sciences, 11(5):640-646

Sangsu, K., Bokyeong, K., Mingyu, C., Nambyun, B., Weonyoung, C. \& Seconyong, L. 1999. Effect of seedling age on growth and yield of machine transplanted rice in southern plain region.Korean Journal of Crop Science, 44:122-128.

Sarwar, N. M.-u.-H. 2011. Impact of nursery seeding density, nitrogen, and seedling age on yield and yield attributes of fine rice. Chilean J. of Agricultural Research, 71(3): 343349.

Shrirame, M. D., Rajgire, H. J. \& Rajgire, A.H. 2000. Effect of spacing and seedling number per hill on growth attributes and yield of rice hybrids under lowland condition. Journal of Soils Crops, 10(1):109-113.

Singh K. N., B. H. (2005). Effect of Nursery Fertilization on Seedling Growth and Yield of Rice. Indian Journal of Agronomy, 50:187-189.

Subedi, R. 2013. Nursery Management Influences Yield and Yield Attributes of Rainfed Lowland Rice. Journal of Sustainable Society, 2: 86-91.

Vijayakumar, M., Sundar Singh, S.D., Prabhakaran, N.K. \& Thiyagarajan, T.M. 2005. Effect of SRI (System of Rice Intensification) practices on the yield attributes, yield and water productivity of rice (Oryza sativaL.). Acta Agronomica, Hungarica, 52(4): 399-408.

Wagh, R. S. 1988. Effect of age of seedlings at transplanting, plant densities and nitrogen fertilization on the yield of rice variety R711. Oryzae, 25: 188-190.

Yoseftabar, S. 2013. Effect nitrogen management on panicle structure and yield in rice (Oryza sativa L.).Intl. J. Agri. Crop. Sci., 5: 1224-1227

Yoshida, S. 1981. Mineral Nutrient of Rice: In Fundamentals of Rice Crop Science. IRRI , pp. 111-146.

Zhilin, L., Sarker, R.S., Nayak, S.K., Ravi, I. \& Li, J.L. 1997. Physiological effect of nitrogen application on aromatic rice. Journal of South China Agricultural University, 18:13-17 